\title{
The Investigation of Cytogenetic and Oxidative Effects of Diffractaic Acid on Human Lymphocyte Cultures
}

\author{
Leyla Demir ${ }^{1}$, Başak Toğar ${ }^{1 *}$, Hasan Türkez ${ }^{2}$, Piera Sozio ${ }^{3}$, Ali Aslan ${ }^{4}$ and Antonio Di \\ Stefano $^{3}$ \\ ${ }^{I}$ Department of Biology; Faculty of Sciences; Ataturk University; Erzurum - Turkey. ${ }^{2}$ Department of Molecular \\ Biology and Genetics; Faculty of Sciences; Erzurum Technical University; Erzurum - Turkey. ${ }^{3}$ Department of \\ Pharmacy; University "G. D'Annunzio "; Chieti - Italy. ${ }^{4}$ Department of Biology, KKEF; Ataturk University; \\ Erzurum - Turkey
}

\begin{abstract}
Diffractaic acid (DA) is a naturally occurring depside derivative found in several lichen species. It has a wide range of important biological effects such as analgesic and antiviral properties, although its cytotoxic, cytogenetic and oxidative effects have not been investigated in human blood tissue yet. Therefore, increasing concentrations (1, 5, 10, 25, 50, 100 and $\left.200 \mathrm{mgL}^{-1}\right)$ of DA was added into human whole blood cultures. 3-(4.5-dimethylthiazol-2-yl)-2.5diphenyl tetrazolium bromide (MTT) assay was used to assess the cell viability and/or cytotoxicity and genotoxic damage potential of DA using chromosome aberration (CA) and micronucleus $(M N)$ tests were performed. In addition, oxidative alterations were determined by the total antioxidant capacity (TAC) and total oxidant status (TOS) assays. The results revealed that DA reduced cell viability at higher concentrations than $50 \mathrm{mgL}^{-1}$. The all tested concentrations of DA were non-genotoxic. In vitro treatments with DA led to increases of TAC levels in the cultured blood cells without changing the TOS levels as compared to the control group. Consequently, DA exhibited a significant non-mutagenic and antioxidant potential in vitro.
\end{abstract}

Key words: Diffractaic acid, cytotoxicity, human blood, genotoxicity, oxidative status

\section{INTRODUCTION}

Nowadays, there is a growing interest in natural substances exhibiting antioxidant properties that could be used by the human and animals as specific preventative pharmaceuticals as (Sarkürkcü et al. 2009). Several studies have been carried out on natural compounds present in the plant antioxidants during the past decade. These antioxidant effects are known to depend on natural compounds present in the plants such as vitamins, fatty acids, lichen, and plant extracts (Türkez and Geyikoğlu 2011; Türkez and Toğar 2013).

Lichens are unique symbiotic organisms that consist of algae (photobionts) and fungi (mycobionts) (Takahagi et al. 2006). There are 25,000 species of lichens in the world. They inhabit over $10 \%$ of the terrestrial surface from arctic to tropical regions and from the plains to the highest mountains (Mitrović et al. 2011). Lichens produce a wide variety of secondary metabolites due to being in various extreme areas (Martins et al. 2010). They are mostly small, but complex molecules and generally exhibit interesting biological effects (Mitrović et al. 2011). In fact, recent studies have shown that these secondary metabolites might have antiproliferative (Bačkorová et al. 2012), antifungal (Goel et al. 2011), antiviral (Sokolov et al. 2012), antimicrobial (Honda et al. 2010), anti-

*Author for correspondence: basaktogar@gmail.com 
inflammatory (Bauer et al. 2012), antitumor (Ari et al. 2012) and antioxidant (Odabaşoğlu et al. 2012) features.

The therapeutic properties of certain medicinal plants are generally related to their content of secondary metabolites, such as polyphenols, terpenes, depsides and alkaloids. Thus, lichens were considered as good sources of natural antioxidants and for pharmaceutical purposes in treating various disorders after their safety evaluations (Kosanić et al. 2011). Diffractaic acid (4-(2,4-dimethoxy-3,6-dimethyl-benzoyl)oxy-2hydroxy-3,6-dimethyl-benzoic acid; $\mathrm{C}_{20} \mathrm{H}_{22} \mathrm{O}_{7}$ ) (DA) is a naturally occurring depside derivative. It is commonly isolated from the lichens such as Usnea longissima, $U$. diffracta, Parmelia tinctorum and P. nepalensis (Bayır et al. 2006). Studies have shown that DA has analgesic, antiviral and antitumoral activities (Okuyama et al. 1995; Yamamota et al. 1995; Neamati et al. 1997). However, the information regarding the cytotoxic, cytogenetic and oxidative effects of DA in human blood cells remain unknown. Therefore, the aim of the present study was to firstly evaluate the cytotoxic/antiproliferative (MTT assay), cytogenetic (MN and CA assays) and oxidative effects (TAC and TOS analysis) of DA on human peripheral blood cultures for its possible use in the complementary and alternative medicine practices.

\section{MATERIALS AND METHODS}

\section{Experimental design}

Human peripheral blood cultures were set up according to a slight modification of the protocol described by Evans and O'Riordan (1975). Human blood samples were obtained from five healthy, non-smokings, non-alcoholic, not under drug therapy and with no recent history of exposure to mutagens; females aged 25-30 years. The heparinized blood $(0.5 \mathrm{~mL})$ was cultured in 6.0 $\mathrm{mL}$ of culture medium (PB-MAX ${ }^{\mathrm{TM}}$ Karyotyping Medium Gibco ${ }^{\circledR} \quad$ Spain) with $5.0 \mathrm{mg} \mathrm{mL} \mathrm{m}^{-1}$ of phytohemagglutinin (Sigma Aldrich ${ }^{\circledR}$, Germany). Diffractaic acid (CAS No. 436-32-8, $\mathrm{C}_{20} \mathrm{H}_{22} \mathrm{O}_{7}$ ) was supplied by ChromaDex Inc ${ }^{\circledR}$ (USA). DA was dissolved in acetone which was then evaporated to dryness at ambient temperature. Human blood samples were treated with final concentrations of $1,5,10,25,50,100$ and $200 \mathrm{mg} \mathrm{L}^{-1}$ of DA. The doses were selected according to Koparal et al. (2006). The cultures without DA were used as control- group Mitomycin C $\quad\left(10 \mu \mathrm{m}, \quad\right.$ Sigma-Aldrich $\left.{ }^{\circledR}\right)$ (Vijayalaxmi et al. 1996) was used as the positive control in MN and CA assays. Ascorbic acid (10 $\mu \mathrm{m}$, Sigma-Aldrich ${ }^{\circledR}$ ) (Türkez 2011) and hydrogen peroxide $\left(25 \mu \mathrm{m}\right.$, Sigma-Aldrich $\left.{ }^{\circledR}\right)$ (Benhusein et al. 2010) were also used as the positive controls in TAC and TOS analysis, respectively.

\section{MTT assay}

Viability of the cells was studied using MTT Cell Proliferation Assay kit (Cayman Chemical Company, Ann Arbor, MI, USA) as described by the manufacturer. After incubation with compounds for $24 \mathrm{~h}, 10 \mu \mathrm{L}$ of MTT solution was added to each well and re-incubated at $37^{\circ} \mathrm{C}$ for $4 \mathrm{~h}$. After washing, the blue formazan was extracted from the cells with isopropanol/formic acid (95:5) and was photometrically determined at $560 \mathrm{~nm}$. The density of formazan formed in the control cells was taken as $100 \%$ viability (Lewerenz et al. 2003).

\section{Chromosomal aberration (CA) assay}

Human lymphocytes were stimulated by DA and cultured for about $72 \mathrm{~h}$. Two hours prior to the harvesting, $0.1 \mathrm{~mL}$ of Colcemid (Gibco ${ }^{\circledR}$, Grand Island, NY) was added to the culture flask. Cells were harvested by centrifugation, treated with a hypotonic solution $\left(0.075 \mathrm{M} \mathrm{KCl}\right.$ at $\left.37.4^{\circ} \mathrm{C}\right)$ Again, the cells were then centrifuged and a solution (methanol + acetic acid) was added three times, and the resulting cells were resuspended and dropped onto clean slides. To prepare the slides, 3-5 drops of the fixed cell suspension were dropped on a clean slide and air-dried. The slides were stained with giemsa in phosphate buffer $(\mathrm{pH}$ 6.8). For each treatment, 30 well-spread metaphases were analyzed to detect the presence of CAs. Criteria to classify the different types of aberrations (chromatid or chromosome gap and chromatid or chromosome break) were in accordance with the recommendation of EHC (Environmental Health Criteria) 46 for environmental monitoring of human populations (IPSC 1985; Türkez and Aydın 2013).

\section{Micronucleus (MN) assay}

Human blood cells were treated with DA and cultured for $72 \mathrm{~h}$. After $44 \mathrm{~h}$ of DA application, cytochalasin B (Sigma-Aldrich ${ }^{\circ}$, final concentration of $6 \mu \mathrm{g} \mathrm{mL}^{-1}$ ) was added. Cells were 
harvested by centrifugation and treated with a hypotonic solution $\left(0.075 \mathrm{M} \mathrm{KCl}\right.$ at $\left.37.4^{\circ} \mathrm{C}\right)$. For the second time, the cells were then centrifuged and a solution (methanol + acetic acid) was added three times, and the resulting cells were resuspended and dropped onto clean slides. To prepare the slides, 3-5 drops of the fixed cell suspension were dropped on a clean slide and airdried. The slides were stained with Giemsa in phosphate buffer ( $\mathrm{pH}$ 6.8) and scored. MN was scored in 1000 binucleated cells and the frequency of cells with MN was determined (Eroğlu 2011).

\section{TAC and TOS analysis}

The assay is calibrated with hydrogen peroxide and the results are expressed in terms of micromolar hydrogen peroxide equivalent per liter ( $\mu$ mol $\mathrm{H}_{2} \mathrm{O}_{2}$ Equiv. L ${ }^{-1}$ ) (Erel 2004, 2005). The automated TAC and TOS assays were carried out by commercially available kits (Rel Assay Diagnostics ${ }^{\circledR}$, Turkey) on plasma samples of DA treated cultures for $2 \mathrm{~h}$.

\section{Statistical analysis}

Statistical analysis was performed using SPSS ${ }^{\circledR}$ software (version 18.0, SPSS, Chicago, IL, USA). The statistical analysis of experimental values in the MTT, CA, MN, TAC and TOS analysis was performed by Duncan's test. Statistical decisions were made with a significance level of 0.05 .

\section{RESULTS}

Cytotoxicity and cell viability were detected by the MTT assay (Fig. 1). The results of MTT analysis showed that DA suppressed the proliferation of human lymphocytes cells, at concentrations high than $50 \mathrm{mg} \mathrm{L}^{-1}$ (at 100 and $200 \mathrm{mg} \mathrm{L}^{-1}$ ) compared to the control value.

Results obtained from the analysis of CAs in human lymphocytes cultured with no treatment $\left(\mathrm{Control}^{-}\right), \mathrm{MMC}\left(\mathrm{Control}^{+}\right)$and treated with different DA concentrations are shown in Figure 2. Evidently different concentrations of DA did not change the rate of CAs when compared with control $^{-}$values. On the contrary, compared to the negative-control group, MMC $\left(10^{-7} \mathrm{M}\right)$ caused considerable increase of CA frequencies (Fig. 3).

Results obtained from the analysis of MNs in human lymphocytes cultured with no treatment $\left(\mathrm{Control}^{-}\right), \mathrm{MMC}\left(\mathrm{Control}^{+}\right)$and treated with different DA concentrations are shown in Figure 4. DA at tested concentrations did not induce significant $(P<0.05)$ number of MNs. However, the MMC applied culture (as positive control) showed about three fold increase of both parameters as compared to the control- group (Fig. $5)$.

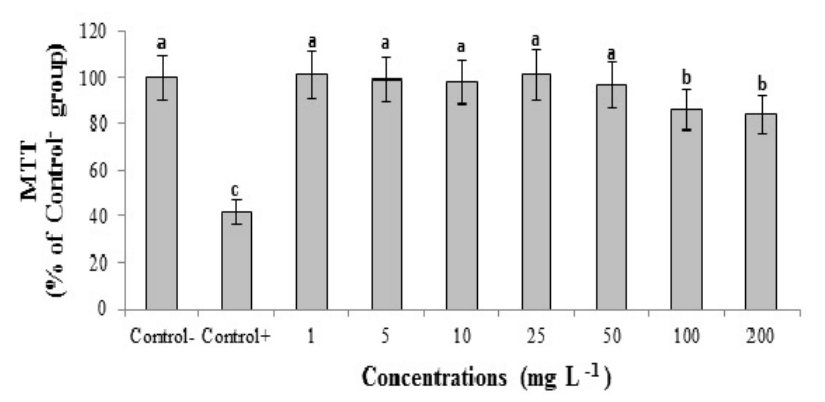

Figure 1 - Cell viability in human blood cultures maintained $24 \mathrm{~h}$ in the presence of DA Control': negative control; Control $^{+}$: positive control; (MMC: $\left.10^{-7} \mathrm{M}\right)$. The bars are shown by different letter are different from each other at a level of 0.05

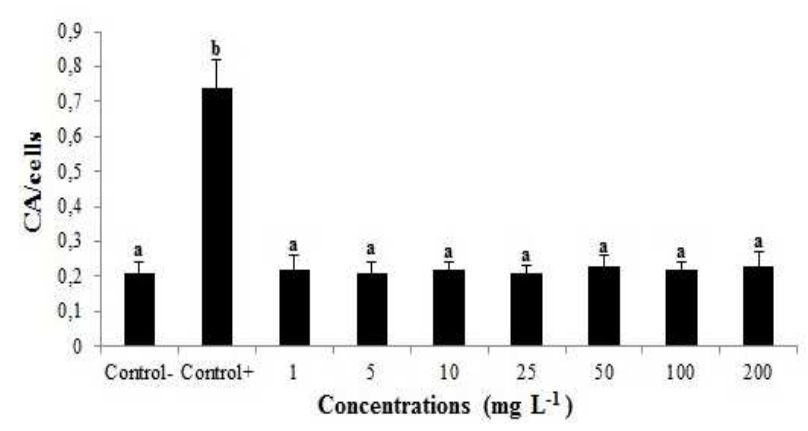

Figure 2 - Chromosome aberration (CA) rates in human lymphocytes after treatment with DA in vitro. The abbreviations are as in Figure 1.

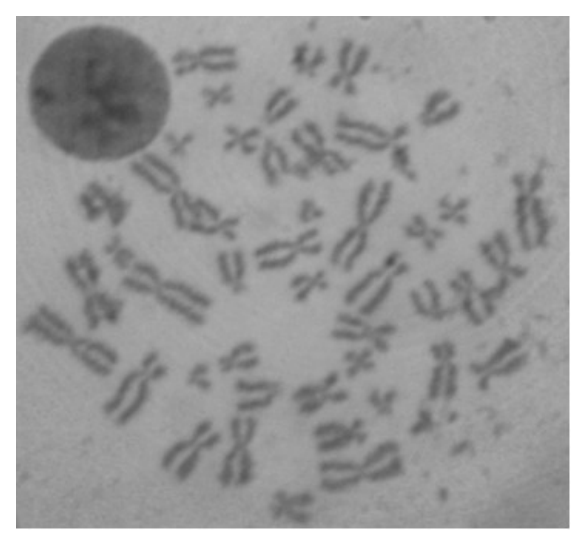

Figure 3 - A sample metaphase from $200 \mathrm{mg} \mathrm{L}^{-1}$ of DAtreated culture x 1000 . 


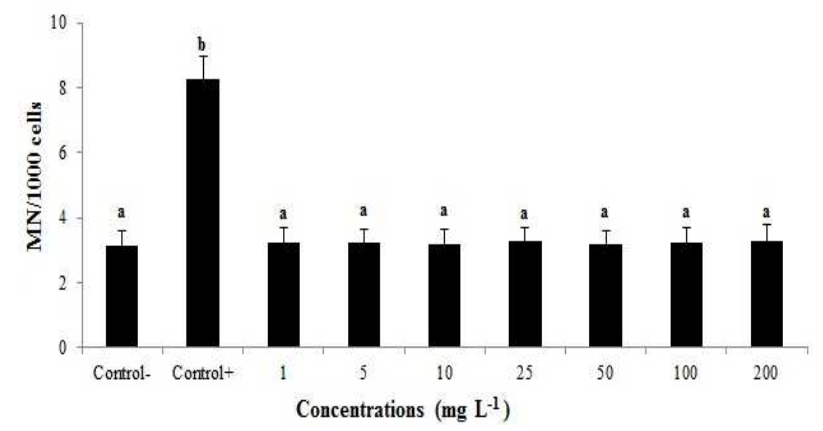

Figure 4 - Micronucleus (MN) rates in human lymphocytes after treatment with DA in vitro. The abbreviations are as in Figure 1.

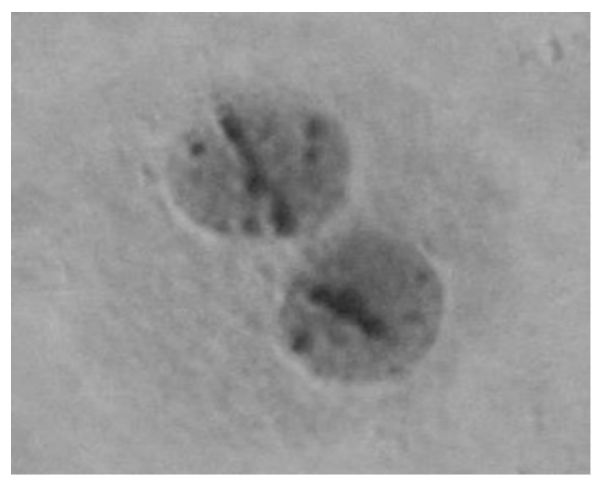

Figure 5 - A sample binucleotid cell from $200 \mathrm{mg} \mathrm{L}^{-1}$ of DA-treated culture $\mathrm{x} 1000$.

Figure 6 shows the comparison of antioxidant profile of DA on cultured human lymphocytes cells. Evidently 1, 5, 100 and $200 \mathrm{mg} \mathrm{L}^{-1}$ concentrations of DA did not lead any alterations in TAC levels while 10,25 and $50 \mathrm{mg} \mathrm{L}^{-1}$ of DA treatments caused significant increase of TAC levels.

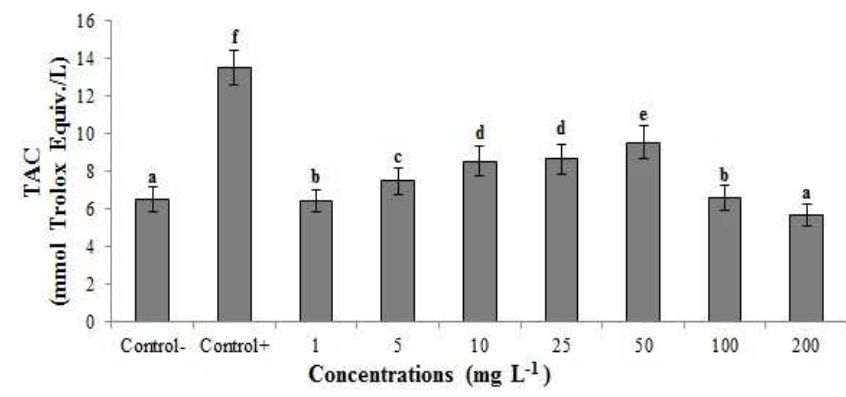

Figure 6 - The level of total antioxidant capacity (TAC) in human blood cultures treated with DA for 24 h. Control': negative control; Control $^{+}$: positive control; (Ascorbic acid: $10 \mu \mathrm{m}$ ). The bars are shown by different letter are different from each other at a level of 0.05 .
Figure 7 shows the effects of DA on TOS parameter in the human blood cells for all the experimental groups. TOS levels were unchanged in negative control and diffractaic acid groups.

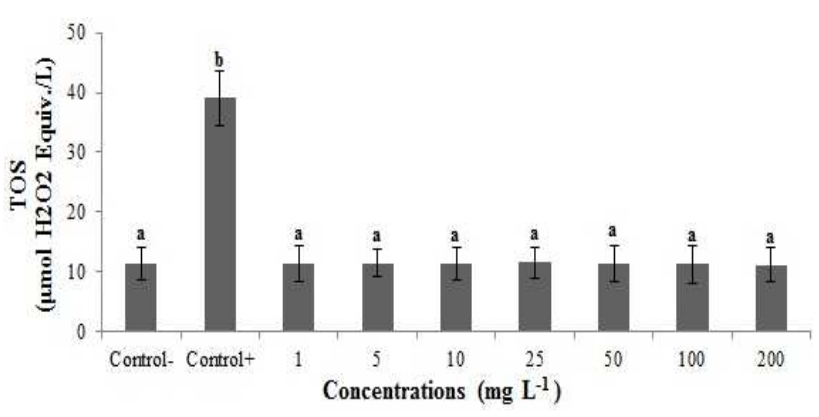

Figure 7 - The level of total oxidant status (TOS) in human blood cultures treated with DA for 24 h. Control': negative control; Control $^{+}$: positive control; (Hydrogen peroxide: 25 $\mu \mathrm{m})$. The bars are shown by different letter are different from each other at a level of 0.05 .

\section{DISCUSSION}

In the present study, the cytotoxic effect of DA were studied on the cultured human blood cells via 3-(4.5-dimethylthiazol-2-yl)-2.5-diphenyl

tetrazolium bromide (MTT) assay, a nonradioactive, fast and economical, which has been widely used to quantify cell viability and proliferation, for the first time. Results showed that DA was not cytotoxic at low concentrations, but it exhibited weak cytotoxic potential at higher concentrations than $50 \mathrm{mg} \mathrm{L}^{-1}$ cultured human blood cells. Similar to these findings, Brisdelli et al. (2013) evaluated the cytotoxicity of DA in several cancer cell lines and found that DA could be cytotoxic for HCT-116, MCF-7 and HeLa cells. Brandão et al. (2013) reported that DA was cytotoxic to UACC-62 cells. It has also been suggested that DA was potent antiproliferative agent against the growth of human keratinocytes (Culberson 1996).

In this study, the genotoxic potential of DA was investigated by using the micronucleus $(\mathrm{MN})$ and chromosome aberration (CA) assays. In fact, CA and $\mathrm{MN}$ assays, as in vitro short-term genotoxicity assays, are widely used to monitor chemicallyinduced damage (Suzuki et al. 2009; Türkez and Geyikoğlu 2010). This study established that DA was non-genotoxic because results did not indicate any significant increase in the ratios of the CAs 
and $\mathrm{MNs}$ in lymphocytes exposed to DA as compared to control values. To our knowledge, there is no information considering the genotoxic effect of DA on cell cultures system. Therefore, its genotoxicity potential could be compared with other lichenic acids. In parallel to the present findings, Leandro et al. (2013) evaluated the genotoxic potential of (+)-usnic acid (UA) by $\mathrm{MN}$ and comet assays in V79 cell cultures and found that that UA did not lead to genotoxicity. Koparal et al. (2006) investigated the genotoxicity of (+)-UA by MN assay in human lymphocytes in vitro and reported that UA was non-genotoxic.

Many of the lichen acids have biological effects due to antioxidant properties. However, only a few reports concerning the antioxidative nature of pure lichen metabolites are available (Neamati et al. 1997; Silva et al. 2010). For assessing the antioxidant/oxidant effects of DA, total antioxidant capacity (TAC) and total oxidant status (TOS) assays were performed. TAC and TOS rapid and reliable automated colorimetric assay are frequently used to determine the oxidative alterations (Kusano and Ferrari 2008). In the present study, 10,25 and $50 \mathrm{mg} \mathrm{L}^{-1}$ concentrations of DA caused significant increases $(P<0.05)$ of TAC levels in human blood cells without changing the TOS levels. Bayir et al. (2006) studied DA for the treatment of gastric lesion induced by indomethacin in the rats and found that DA supported the antioxidant defense systems. Jayaprakasha and Rao (2000) demonstrated that methyl orsellinate, atranorin, osellinic acid and lecanoric acid exhibited antioxidant effect. Likewise, sekikaic acid and homosekikaic acid showed antioxidant activity in 1,1-diphenyl-2-picrylhydrazyl radical (DPPH) radical scavenging assay (Sisodia et al. 2013). Manojlovic et al. (2012) found that salazinic acid, norstictic acid, atranorin, and UA exhibit higher DPPH and hydroxyl radical scavengings, and inhibitory activity towards lipid peroxidation. On the other hand, Brisdelli et al. (2013) found that the tested lichen acids (DA, UA, lobaric acid, vicanicin, variolaric acid, protolichesterinic acid) did not exhibited the highest radical scavenging activity using the 1,1-diphenyl-2-picrylhydrazyl (DPPH) assay. Kumar and Müller (1999) suggested that protolichesterinic acid neither acted as antioxidants against the peroxidation process in model membranes nor did they scavenge or produce free radicals.

\section{CONCLUSION}

In conclusion, the present results clearly revealed that DA had no mutagenic effect on human blood cell cultures. Moreover, DA exhibited weak cytotoxic and high antioxidant properties due to the used concentrations. On the basis of the in vitro results, DA appeared to be good and safe natural antioxidant and also, could be of significance in human therapy, animal and plant diseases.

\section{ACKNOWLEDGEMENTS}

The authors are grateful to all volunteers for the blood samples.

\section{REFERENCES}

Ari F, Celikler S, Oran S, Balikci N, Ozturk S, Ozel MZ, et al. Genotoxic, cytotoxic, and apoptotic effects of Hypogymnia physodes (L.)Nyl.on breast cancer cells. Environ Toxicol. 2012; 10: 1002-21809.

Bačkorová M, Jendželovský R, Kello M, Bačkor M, Mikeš J, Fedoročko P. Lichen secondary metabolites are responsible for induction of apoptosis in HT-29 and A2780 human cancer cell lines. Toxicol In Vitro. 2012; 26: 462-468.

Bauer J, Waltenberger B, Noha SM, Schuster D, Rollinger JM, Boustie J, et al. Discovery of depsides and depsidones from lichen as potent inhibitors of microsomal prostaglandin E2 synthase-1 using pharmacophore models. Chem Med Chem. 2012; 7: 2077-2081.

Bayir Y, Odabasoglu F, Cakir A, Aslan A, Suleyman H, Halici $M$, et al. The inhibition of gastric mucosal lesion, oxidative stress and neutrophil-infiltration in rats by the lichen constituent diffactaic acid. Phytomedicine. 2006; 13: 584-590.

Benhusein GM, Mutch E, Aburawi S, Williams FM. Genotoxic effect induced by hydrogen peroxide in human hepatoma cells using comet assay. Libyan $J$ Med. 2010; 13:5

Brandão LF, Alcantara GB, Matos Mde F, Bogo D, Freitas Ddos $\mathrm{S}$, et al. Cytotoxic evaluation of phenolic compounds from lichens against melanoma cells. Chem Pharm Bull. 2013; 61: 176-183.

Brisdelli F, Perilli M, Sellitri D, Piovano M, Garbarino JA, Nicoletti $M$, et al. Cytotoxic activity and antioxidant capacity of purified lichen metabolites: an in vitro study. Phytother Res. 2013; 27: 431-437.

Culberson CF. Chemical and Botanical Guide to Lichen Products. Chapel Hill:The University of North Carolina Press, 1996; 628p. 
Erel O. A new automated colorimetric method for measuring total oxidant status. Clin Biochem. 2005; 38: 1103-1111.

Eroğlu HE. The cytogenetic effects of black tea and green tea on cultured human lymphocytes. Braz Arch Biol Technol. 2011; 54: 1159-1165.

Evans HJ, O'Riordan ML. Human peripheral blood lymphocytes for the analysis of chromosome aberrations in mutagen tests. Mut Res. 1975; 31: 135148.

Goel M, Dureja P, Rani A, Uniyal PL, Laatsch H. Isolation, characterization and antifungal activity of major constituents of the Himalayan lichen Parmelia reticulata Tayl. J Agric Food Chem. 2011; 59: 22992307.

Honda, NK, Pavan, FR, Coelho, RG, de Andrade Leite SR, Micheletti AC, Lopes TI, et al. Antimycobacterial activity of lichen substances. Phytomedicine. 2010; 17: 328-332.

IPCS. (International Program on Chemical Safety), Environmental Health Criteria 46. Guidelines for the Study of Genetic Effects in Human Populations. WHO, Geneva 45-1985; 54.

Jayaprakasha GK, Rao LJ. Phenolic constituents from the lichen Parmotrema stuppeum (Nyl.) Hale and their antioxidant activity. $Z$ Naturforsch C. 2000; 55: 1018-1022.

Koparal AT, Tüylü BA, Türk H. In vitro cytotoxic activities of (+)-usnic acid and (-)-usnic acid on V79, A549, and human lymphocyte cells and their nongenotoxicity on human lymphocytes. Nat Prod Res. 2006; 20: 1300-1307.

Kosanić M, Rankovic B. Antioxidant and antimicrobial properties of some lichens and their constituents. $J$ Med Food. 2011; 14: 1624-1630.

Kumar KC, Müller K. Lichen metabolites. 1. Inhibitory action against leukotriene B4 biosynthesis by a nonredox mechanism. J Nat Prod. 1999; 62: 817-820.

Kusano C, Ferrari B. Total antioxidant capacity: a biomarker in biomedical and nutritional studies. $J$ Cell Mol Biol. 2008; 7: 1-15.

Leandro LF, Munari CC, Sato VL, Alves JM, de Oliveira PF, Mastrocola DF, et al. Assessment of the genotoxicity and antigenotoxicity of (+)-UA in V79 cells and Swiss mice by the micronucleus and comet assays. Mutat Res. 2013; 753: 101-106.

Lewerenz V, Hanelt S, Nastevska C, El-Bahay C, Rouhrdanz E, Kahl R. Antioxidants protect primary rat hepatocyte cultures against acetaminopheninduced DNA strand breaks but not against acetaminophen induced cytotoxicity. Toxicol. 2003; 191: 179-87.

Manojlovic NT, Vasiljevic PJ, Maskovic PZ, Juskovic M, Bogdanovic-Dusanovic G. Chemical composition, antioxidant, and antimicrobial activities of lichen Umbilicaria cylindrica (1.) delise (Umbilicariaceae). Evid Based Complement Alternat Med. 2012; 2012: 452431.
Martins MCB, de Lima MJG, Silva FP, AzevedoXimenes E, da Silva NH, Pereira EC. Cladia aggregata (lichen) from Brazilian northeast: chemical characterization and antimicrobial activity. Braz Arch Biol Technol. 2010; 53: 115-122.

Mitrović T, Stamenković S, Cvetković V, Tošić S, Stanković M, Radojević I, et al. Antioxidant, antimicrobial and antiproliferative activities of five lichen species. Int J Mo. Sci. 2011; 12: 5428-5448.

Neamati N, Hong H, Mazumder A, Wang S, Sunder S, Nicklaus MC, et al. Depsides and depsidones as inhibitors of HIV-1 integrase: discovery of novel inhibitors through 3D database searching. J Med Chem. 1997; 40: 942-951.

Odabaşoglu F, Yildirim OS, Aygun H, Halici Z, Halici M, Erdogan F, et al. Diffractaic acid, a novel proapoptotic agent, induces with olive oil both apoptosis and antioxidative systems in Ti-implanted rabbits. Eur J Pharmacol. 2012; 674: 171-178.

Okuyama E, Umeyama K, Yamazaki M, Kinoshita Y, Yamamoto $Y$. Usnic acid and diffractaic acid as analgesic and antipyretic components of Usnea diffracta. Planta Medica. 1995; 61: 113-115.

Sarikürkcü C, Arisoy K, Tepe B, Cakir A, Abali G, Mete E. Studies on the antioxidant activity of essentialoil and different solvent extracts of Vitexagnuscastus L. fruits fromTurkey. Food Chem Toxicol. 2009; 47: 2479-2483.

Silva JA, Bomfim RR, Estevam Cdos S, Antoniolli AR, Araújo AA, Thomazzi SM. Pharmacological properties of lichen Cladonia clathrata. Pharm Biol. 2010; 48: 745-752.

Sisodia R, Geol M, Verma S, Rani A, Dureja P. Antibacterial and antioxidant activity of lichen species Ramalina roesleri. Nat Prod Res. 2013; 27: 2235-2239.

Sokolov DN, Zarubaev VV, Shtro AA, Polovinka MP, Luzina OA, Komarova NI, et al. Anti-viral activity of $(-)$ - and (+)-usnic acids and their derivatives against influenza virus $\mathrm{A}(\mathrm{H} 1 \mathrm{N1}) 2009$. Bioorg Med Chem Lett. 2012; 22: 7060-7064.

Suzuki H, Takasawa H, Kobayashi K, Terashima Y, Shimada Y, Ogawa I, et al. Evaluation of a liver micronucleus assay with 12 chemicals using young rats (II): a study by the Collaborative Study Group for the Micronucleus Test/Japanese Environmental Mutagen Society-Mammalian Mutagenicity Study Group. Mutagenesis. 2009; 24: 9-16.

Takahagi T, Ikezawa N, Endo T, Ifuku K, Yamamoto Y, Kinoshita Y, et al. Inhibition of PSII in atrazinetolerant tobacco cells by barbatic acid, a lichenderived depside. Biosci Biotechnol Biochem. 2006; 70: 266-268.

Türkez H and Geyikoğlu F. The efficiacy of bismuth subnitrate against genotoxicity and oxidative stress induced by aluminum sulphate. Toxicol Ind Health. 2011; 27: 133-142. 
Türkez H, Toğar B. Aluminum phosphide-induced genetic and oxidative damages in rats: attenuation by Laurus nobilis leaf extract. Toxicol Ind Health. 2013; 29: 579-583.

Türkez H, Aydın E. The genoprotective activity of resveratrol on permethrin-induced genotoxic damage in cultured human lymphocytes. Braz Arch Biol Technol. 2013; 56: 405-401.

Türkez H, Geyikoğlu F. Boric acid: a potential chemoprotective agent against aflatoxin B(1) toxicity in human blood. Cytotechnology. 2010; 62: 157-165.

Türkez H. The role of ascorbic acid on titanium dioxide-induced genetic damage assessed by the comet assay and cytogenetic tests. Exp Toxicol Pathol. 2011; 63: 453-457.
Vijayalaxmi, Reiter RJ, Leal BZ, Meltz ML. Effect of melatonin on mitotic and proliferation indices, and sister chromatid exchange in human blood lymphocytes. Mutat Res. 1996; 351: 187-192.

YamamotaY, MiuraY, KinoshitaY, Higuchi M, Yamada Y, Murakami A, et al. Screening of tissue cultures and thalli of and some of their active constituents for lnhibition of tumor promoter lnduced epstein - barr virus activation Chem Pharm Bull. 1995; 43: 1388-1390.
Received: January 20, 2014; Accepted: April 24, 2014. 